\title{
'Virtually' the same learning outcomes. A case study of a virtual client briefed communication project across borders
}

\author{
'Virtualmente' los mismos resultados de aprendizaje. \\ Un caso de estudio de un proyecto de \\ comunicación internacional
}

\section{'Virtualmente' os mesmos resultados de aprendizagem. Um estudo de caso de um projeto integrado de comunicação internacional}

\author{
Alexandre Duarte \\ Centro de Estudos, Comunicação e Sociedade \\ (University of Minho) \\ https://orcid.org/0000-0002-2665-864X \\ Portugal \\ Kirstie Riedl \\ FHWien der WKW \\ (University of Applied Sciences for Management \& Communication) \\ https://orcid.org/0000-0001-6405-459 \\ Austria
}

Reception date: 2 February 2020

Review date: 5 February 2021

Accepted date: 22 May 2021

Published: 1 July 2021

To cite this article: Duarte, A. \& Riedl , K. (2021). 'Virtually' the same learning outcomes. A case study of a virtual client briefed communication project across borders, Icono 14, 19(2), 189-211. doi: 10.7195/ri14.v19i2.1724 


\section{Abstract}

As the world becomes increasingly more turbulent, complex and competitive, there has been an increased interest in creativity as the major force to prepare students for these demands. At the same time, digital native students today are used to working in an environment rich with instantly accessible information and knowledge, yet paradoxically students are less satisfied with their courses in the online environment. Educators are thus challenged to use innovative methods to nurture creativity online as they would do in the face-to-face classroom.

In 2010, six European universities created an international project, named Cross Border Brand Communication ( $C B B C$ ) that has taken place every year since, but in 2020 it took place online due to the Covid-19 pandemic. This article describes and analyzes the best practices resulting from this case and addresses the research questions as to whether the creative learning outcomes and teaching practices online are the same as face-to-face and to what extent are students satisfied with this learning environment. Focus group discussions with a small group of students and the lecturers involved facilitated an in-depth reflection on the project and the case indicates that although learning outcomes online are "virtually" the same, the student experience is inferior to such face-to-face projects.

Keywords: Teaching creativity; Creative learning; Distance learning; Online learning barriers; Perceived learning; Learning outcomes and skills

\section{Resumen}

A medida que el mundo se vuelve cada vez más turbulento, complejo y competitivo, ha habido un mayor interés en la creatividad como la fuerza principal para preparar a los estudiantes para esto. Los estudiantes nativos digitales de hoy en día están acostumbrados a trabajar en un entorno rico en información y conocimientos accesibles al instante, pero los estudiantes están menos satisfechos con sus cursos en el entorno en línea. Al mismo tiempo, los educadores deben utilizar métodos innovadores para fomentar la creatividad en línea, como lo harían en el aula presencial.

En 2010, seis universidades europeas crearon un proyecto internacional, llamado Cross Border Brand Communication (CBBC) que se ha llevado a cabo todos los años 
'Virtually' the same learning outcomes. A case study of a virtual client briefed... | 191

MONOGRAPH

desde entonces, pero en 2020 se llevó a cabo en línea debido a la pandemia de Covid-19. Este artículo describe y analiza las mejores prácticas resultantes de este caso y aborda las preguntas de investigación sobre si los resultados del aprendizaje creativo y las prácticas de enseñanza en línea son los mismos que los presenciales y en qué medida los estudiantes están satisfechos con este entorno de aprendizaje. Se realizaron encuentros con un grupo de alumnos y con los profesores involucrados, lo que contribuyó a una profunda reflexión sobre el proyecto, lo que apunta a que, aunque los resultados del aprendizaje en línea son "virtualmente" los mismos, la experiencia del estudiante es inferior a la de esos proyectos presenciales.

Palabras clave: Creatividad en la enseñanza, Aprendizaje creativo, Aprendizaje a distancia, Barreras de aprendizaje online, Aprendizaje percibido, Resultados y satisfacción del aprendizaje

\section{Resumo}

$\grave{A}$ medida que o mundo se torna cada vez mais turbulento, complexo e competitivo, tem havido um aumento do interesse pela criatividade como a principal força para preparar os alunos para esta nova realidade. Os alunos nativos digitais de hoje estão acostumados a trabalhar num ambiente rico de informações e conhecimento instantânea e permanentemente acessiveis, mas os alunos estão menos satisfeitos com os seus cursos em ambiente virtual. Ao mesmo tempo, os educadores são obrigados a usar métodos cada vez mais inovadores para estimular a criatividade online, como fariam na sala de aula presencial.

Em 2010, seis universidades europeias criaram um projeto internacional, denominado Cross Border Brand Communication ( $C B B C)$, que ocorre todos os anos desde então, mas em 2020 foi realizado online devido à pandemia de Covid-19. Este artigo descreve e analisa as melhores práticas resultantes deste caso e aborda as questões de pesquisa sobre se os resultados de aprendizagem criativos e as práticas de ensino online são iguais aos presenciais e em que medida os alunos estão satisfeitos com este ambiente de aprendizagem. Foram realizadas reuniões com um grupo de alunos e com os professores envolvidos, que contribuíram para uma reflexão profunda sobre o projeto, que aponta para o facto de, embora os resultados da aprendizagem online sejam "virtualmente" os mesmos, a experiência do aluno é avaliada de forma inferior relativamente a esses projetos presenciais. 
MONOGRAPH

Palavras chave: Ensino de criatividade, Aprendizagem criativa, Ensino à distância, Barreiras de aprendizagem online, Aprendizagem percebida, Resultados e satisfação da aprendizagem

\section{Introduction}

Virtual learning has been a contentious topic in education for at least 20 years, with educators often having a carte blanche to include it in the curriculum or not. The 2020 Covid-19 pandemic saw that this choice was taken, at least for the duration of the lock-down, which at its peak in March 2020 saw 167 countries implementing country-wide closures of education institutions, impacting over $82 \%$ of global learners (UNESC0, 2020). The longevity of the pandemic has meant that educators have become accustomed to this form of instruction and there is indication online learning will become more prevalent, so the questions around learning outcomes in the virtual environment have become even more pressing. This article reviews the existing literature on virtual learning compared to face-to-face learning and the importance of creativity in the learning process. Subsequently, it describes an international project, which was established in 2010 by six European Universities and has taken place every year since. It reflects on the impact on learning outcomes by carrying out the project online in 2020 due to the Covid-19 pandemic. The purpose of this paper is to contribute to the ever-expanding knowledge of learning and teaching creativity online.

\subsection{Teaching Creativity}

\subsubsection{Global and complex world}

The globalized society has brought new problems, new challenges as well as interdisciplinary concerns to the fore, demanding students' critical, creative, and practical skills in order to be successful (McWilliam \& Dawson, 2008; Livingston, 2010; Vanada, 2016). As the world becomes increasingly turbulent, complex and competitive, numerous authors (Brinkman, 2010; Clegg, 2008; Saebø et al., 2007) have noted the current interest being paid to creativity as a major force to prepare young people to deal with this VUCA world. Of course, this also impacts Higher 
'Virtually' the same learning outcomes. A case study of a virtual client briefed... $\mid 193$

MONOGRAPH

Education Institutions (HEI). As Gustina and Sweet (2014) suggest: "this potential arises out of the recognition by leaders in the developed world that creativity leads to innovation, and innovation leads to economic growth. Leaders in many countries are calling for more emphasis on the development of creativity in education" (p.52).

Classic industrialist models of teaching and learning, that emphasize an assembly of facts to be remembered on tests, with isolation between subjects and presented in linear ways, are no longer enough to provide the skills that our graduates will need in the context of globalization and creative economies (Saebø et al., 2007; Vanada, 2016). Almost all 21st century college students have the predisposition, skills and technology to access facts quickly, as they live in this world of instant access. Of course, discipline-specific facts are important, but even more fundamental is to know how to think critically and creatively to solve problems, collaborate in teams, use rhetoric to aptly construct an argument, and enact their social-emotional skills (Vanada, 2016).

\subsubsection{Creativity as/is the answer}

The British NACCCE report "All our futures", UNESCO or the European University Association (EUA) - just to name a few of the major organizations - all point out that no education system can be world-class without valuing and integrating creativity in teaching and learning. UNESCO proclaimed that "Creativity is our hope", and the EUA report has responded by directing the entire higher education sector to consider creativity as central to research and teaching:

The complex questions of the future will not be solved "by the book", but by creative, forward-looking individuals and groups who are not afraid to question established ideas and are able to cope with the insecurity and uncertainty that this entails. (as cited in McWilliam, 2009, p.284)

\subsubsection{Problem-solving focus}

Although research on advertising creativity is abstruse, as well as limited due to the abstract nature of creativity (Ahmad et al., 2017), it would appear that the 
current discourse suggests that creativity is an essential element of problem solving and this is gaining ground and continually evolving (Gustina \& Sweet, 2014; Runco, 2004). Saebø et al. (2007) suggest that creativity is good for the economy, good for the individual, good for society and good for education.

Livingston (2010) additionally proposes that that practicing problem solving as a team game should be part of every student's experience and educators should focus their efforts on how graduates should be, and not just on what they should know. If the goal is to teach students to improve their creative problem-solving skills, creativity training should focus on helping them to learn a collection of general strategies and know when to use them (Dow \& Mayer, 2004). When we do that, problem solving becomes the driving pedagogy. McWilliam and Dawson (2008) additionally remind us that all university graduates will be engaged in work that is less focused on routine problem-solving and more focused on interactivity, navigation capacity, forging relationships, tackling novel challenges and synthesizing 'big picture' scenarios for the purposes of adding a competitive commercial edge.

\subsubsection{The teaching paradox}

As in all teaching-learning process, the role of the instructor is crucial. Teaching creativity poses a challenge for instructors because it is a complex phenomenon and a multifaceted skill that is not easily taught "by showing slides and talking about theory" (Karpova et al., 2011, p.53). Sawyer (2017) found that students prefer instructors who assist them with enthusiasm, who understand the problem from their perspective, accept and help them develop their ideas. The problem lies within the more conceptual assignments and the ambiguity of expected outcomes in the creative disciplines versus the more linear, numeric, logic and rational expected outputs from that of the exact sciences, for instance. The creative and conceptual assignments are the most challenging for students and they have more difficulty when the studio pedagogy is completely open-ended as they do not know how to solve ill-defined problems and they become confused (Chen, 2016). This tension between the importance of open-ended assignments to foster creativity, and the contrasting need for structure to effectively guide the learning process is commonly faced by many teachers. Sawyer (2017) refers to this as the 
'Virtually' the same learning outcomes. A case study of a virtual client briefed... | 195

MONOGRAPH

teaching paradox which is the difficulty in fostering creative learning through constructivist methods, while at the same time providing the appropriate level of structure and scaffolding. Even so, he found that the majority of students "value interactions where the instructor provides advice and provides expert feedback and guidance" and "understand that there is a need for both open-endedness and structure, and most are happy with how the balance was addressed" (p.107).

\subsubsection{Constructivism/learner-centered education}

In order to develop creative, yet self-directed and resilient thinkers and learners, Sir Ken Robinson (2001), the author of one of the most viewed ted talks ${ }^{1}$ ever, argued that constructivist philosophy is a move away from classic industrialist models of teaching and learning where each subject is taught isolated from others. There is a move towards a more holistic paradigm, where learning is more integrative and organized around problems, instead of specific discipline content. This learning approach is aligned with the most recent research, which has found that such pedagogies are more effective at fostering better learning outcomes (Nathan \& Sawyer, 2014).

One of the most used practices of this constructivist pedagogy lies in the socalled studio classes. Studio is the name commonly used for learning environment designs within which students actively engage in creative work under the guidance of an instructor, where the instructor acts not as an authority figure who presents information as the expert, but rather as a guide and facilitator (Sawyer, 2017). In these classes, students play an important role in the learning system (Chen, 2016) as they are active participants in the construction of their own knowledge along the process. In those less formal spaces, teachers engage in dialogue with students, helping them to learn how to evaluate their own work and the work of their peers, and class sessions focus on learning by doing (Salazar, 2013). Since the flow of these studio sessions are flexible and improvised, students are encouraged to make decisions, experiment, take risks, and occasionally to fail (Sawyer, 2017), which is critical in the creative process. Vanada's (2016) research also found that students performed better when the instructor used this approach and they are granted substantial autonomy in these learner-centered classrooms, in the belief 
that they will learn more effectively if they experiment and take risks. As Sawyer (2017) stated, rather than a formal evaluation resulting in a course grade, the interactions in the constructivist philosophy are designed with a pedagogical intent, while the students are guided along their own path by the instructors.

\subsubsection{Learning by doing}

We must bear in mind that learning is no longer considered an accumulation of facts, but rather the ability to construct knowledge in meaningful ways toward a well-defined problem (Bransford et al., 2000, as cited in Vanada, 2016), and one of the best ways to do it is through learning by doing.

There is plentiful literature on teaching creativity and/or teaching creatively (e.g. Jeffrey \& Craft, 2004; Karpova et al., 2011; Lindström, 2006; Saebø et al., 2007). For educators the focus should be on learning, not teaching and indeed, if learning is the goal, we need to rethink all the pedagogical constructs, such as the classic lecture, the role of the teacher, the format and organization of the classrooms that have long stood as absolutes in the university catechism. As Livingston (2010) suggests, the classroom lecture format is not, by its own nature, a natural laboratory for interaction and collaboration. On the other hand, the studio format helps students to learn from their own experiences rather than from formal teaching, because the learning environment is designed in order to students actively engage in creative work under the guidance of an instructor that use a learner-centered approach rather than a teacher-centered approach (Sawyer, 2017). This is in line with the EUA report that stated: "Institutions are slowly moving away from a system of teacher-driven provision, and towards a student-centered concept of higher education" (Crosier et al., 2007, p.7).

Another central point, emphasized by Chen (2016), is the opportunity to work with actual/real problems because it increases acquiring professional knowledge and techniques. Much of what is presented in the typical classroom can be easily acquired on the Internet, so if students are presented with challenges that allow them to make creative choices about how to proceed, the role of the instructors is "walking a line between driving students in a particular direction and encouraging students to act 
independently" (Adams \& Forin, 2016, p.61). In fact, nowadays, almost everything can be found on the internet and virtually everything can be studied at home by a student who is motivated, enterprising, and technically adept. However, what is lacking at home, as Livingston (2010, p.60) points out, is "the access to this community that includes teachers and students alike, who provide opportunities for sparking and enlarging one's creative processes". After all, creativity is not as private and individual process as we often imagine, but rather part of a social and cultural context.

\subsubsection{Virtual Learning}

Online learning in tertiary education manifests itself in different formats ranging from completely distance / online such as those courses offered at the 0pen University and increasingly M00Qs, to blended or hybrid formats which are becoming more popular at traditional universities to offer students a variety of didactic methods. Due to the Covid-19 pandemic, universities were forced to put all courses online overnight, and this was arguably the kick-start educators needed to modernize methods. As with other businesses and industries, universities have seen the effectiveness and indeed necessity of online courses and so this will certainly feature more frequently in the future.

There is dispute in the academic community about agreed quality measures for online education (Allen \& Seaman, 2015; Markova, Glazkova \& Zaborova, 2017). However, Eom et al. (2006) suggest that perceived learning outcomes and student satisfaction are the widely accepted measures of online education (p.216). The authors used a survey to determine the factors which contribute to the success, showing that course structure, self-motivation, learning styles, instructor knowledge and facilitation, interaction and instructor feedback were key (p. 228). Bangert (2005, pp. 90-91) likewise investigated factors improving the quality of online teaching and student satisfaction and found that there are four critical measures: interaction between students and teachers, time dedicated to the task, active learning as well as peer cooperation.

Further disagreement is around what students prefer; online, blended/hybrid or face-to-face education. From our anecdotal experience teaching both formats in 


\section{MONOGRAPH}

Austria and Portugal, we can report that with asynchronous online teaching, students have the chance to learn at their own pace with time for consideration and reflection. At the same time, students can more easily get confused and frustrated. Whether there is generally increased student satisfaction in face-to-face teaching compared to online teaching is problematic due to the debate as to what metrics can be used to measure quality. However, Allen and Seaman (2015) probed this by asking course managers to self-evaluate the relative quality of learning outcomes. Their study revealed that $15.5 \%$ of academic leaders regarded online learning outcomes as "somewhat superior" compared to $35.9 \%$ who claimed they are "somewhat inferior" (p. 18). Notwithstanding this, managers in this investigation were more likely to rate online learning more negatively if their institutions did not offer online offerings, a fact that suggests these results should be taken with care as those managers are hardly in the position to comment without this experience. In another broad survey, Markova et al. (2017) investigated the effectiveness of distance learning and found that just $5.7 \%$ of respondents evaluated their online learning as more effective. Issues uncovered include "low self-organization, lack of control on the instructor's side, lack of effective interaction and sense of isolation" (p. 690). Another study to investigate blended versus face-to-face was undertaken by Tseng and Walsh (2016) but this time from the student perspective. Their investigation revealed that motivation and learning outcomes in the blended course were significantly higher than in the traditional course and those students in the blended course preferred this format and would recommend it to their peers (p.14). This blended or hybrid course format (part online, part face-to-face) was also shown to contribute to improved learning effectiveness in the study carried out by Riffell and Sibley (2005, p. 233).

The lack of control and interaction identified by Markova et al. is echoed in the survey by Shea et al. (2006), where it was revealed that higher levels of learning occurred when instructors exhibited more "teaching presence" (p. 184). "Meaningful interaction" is even more so important in web-based learning as discussed at length by Woo and Reeves (2007). Instructors must also ensure that effective course organization is crucial in online learning to avoid disengagement. Eom et al. (2006) describe the lecturer's role as shifting to becoming more of a facilitator than a teacher. They cite three models of interaction, which are imperative for suc- 
'Virtually' the same learning outcomes. A case study of a virtual client briefed... | 199

MONOGRAPH

cessful online teaching which include the interaction with the materials, with the tutors and with their peers (Moore 1989, cited by Eom et al. 2006, pp. 219-221).

There have been a few recent studies reviewing student learning outcomes in light of the Covid-19 pandemic. Jia et al. (2020) looked at the success of the online "flipped classroom" and found that they were just as successful as in the face-toface format. The authors noted this is possible by ensuring social, cognitive, teaching presence and maintaining student attention using different teaching methods, humour and students keeping their webcams switched on (pp 15-17). However, another study undertaken by Orlov et al. (2020) investigated the effects of the pandemic on student learning across 4 institutions in the US, and they found that student outcomes did suffer and the "declines in learning were not trivial" (p.2). Hanan's (2020) survey in India and South Korea looked into students' perceived learning outcomes and their influence on student satisfaction which indicated that the course structure indirectly influences the students' perceived learning outcomes and satisfaction. A very recent survey was undertaken by the University of Applied Science for Management and Communication in Vienna encompassing over 500 students to capture students' perceptions about the change from faceto-face to online learning due to the Covid-19 pandemic. It showed that although $32.5 \%$ of students would like to have more online learning in the future, $62.1 \%$ believe they would have learnt more if they had had face-to-face classes. Interviews were also carried out with one student revealing "pure distance teaching is an extreme change for me, it makes group work especially difficult" (Pezenka et al., 2020).

\section{Method}

\subsection{Background}

The Cross Border Brand Communication Project (CBBC) was founded in 2010 by a selected consortium of European Universities, which now includes universities from Portugal (IADE Lisbon), Austria (FHWien der WKW, Vienna), The Netherlands (Breda University of Applied Sciences), Belgium (AP Hogeschool Antwerpen), Finland (Haaga-Helia University of Applied Sciences) and France (Sup de Pub, Paris). 


\section{MONOGRAPH}

It could be described as the epitome of the constructivist learning environment as students have to work creatively to solve the client problem. These universities nominate 6 students for the week long deep dive into a real client marketing communication issue. It is organized as follows. The universities take turns each year to host the project and it is the responsibility of the host university to locate a client with a communication challenge. The students, exclusively from Communication areas (advertising, design, media and multimedia), and ideally from the 2nd year, are selected a few months in advance according their attitude, capacity and skills. Each national team receives the client brief in advance, which they use as a basis for some initial research from the point of view of their local market. At the start of the week, after every country has presented their research findings, they are allocated into international teams (ideally one student from each country, each with a different self-identified expert role of either strategist, creative or designer) and receive a communication briefing from a real client, with a real problem that each group should solve with a $360^{\circ}$ communication proposal. For the rest of the week every group acts as an advertising agency, and works intensively on the project, starting by defining a strategy, proposing a creative campaign with media planning, and culminating in a "pitch" to the client on the Friday afternoon. There are 6 lecturers from each of the universities present for the entire week, who coach and advise the students as they progress and offer a stimulating mini-lecture each morning. The following learning outcomes apply to the CBBC project:

- Apply the acquired knowledge to a real job in a professional context

- Analyze real-word oriented communication approaches

- Define objectives, strategies, communication measures and their integration budgeting and controlling in a coherent concept and develop feasible solutions

- Implement real-world relevant information into a concept

- Present and argue in favor of concepts in a convincing manner

- Reflect on discussions from the coaching process and draw conclusions

- Co-operate and collaborate with students from other countries, understand different cultural backgrounds. 
'Virtually' the same learning outcomes. A case study of a virtual client briefed... $\mid 201$

MONOGRAPH

The 2020 CBBC edition was going to take place at the University of Applied Sciences in Breda, the Netherlands in May 2020, but due to the Covid-19 pandemic, it had to be cancelled and all 6 institutions agreed to trial it online. As such, a further learning outcome was added to the above:

- Work effectively with appropriate tools and strategies online

Notably, not all students were enthusiastic about this and each lecturer reported students being reluctant to take part in the online version resulting in some universities having fewer participants. The client that year was a well-known brand of adhesive tape in the Benelux markets who briefed the students to come up with a creative campaign to communicate the sustainability efforts of the organization.

\subsection{Research Questions and Objectives}

The findings from the literature review show that there are considerable challenges to teaching creativity in such projects effectively online and this situation lends itself to the following research questions, which this investigation will now address:

- To what extent are the learning outcomes "virtually" the same in online and face-to-face creative projects?

- How does teaching creativity online differ from face-to-face teaching?

- To what extent are students satisfied with practical online teaching?

As discussed in the literature review the quality of online education can be identified by reviewing student satisfaction and perceived learning outcomes. Against this backdrop, the objective of this study is to shed light on the challenges and differences of teaching creative projects online and will inform educators on best practices and pitfalls to avoid to achieve learning outcomes and student satisfaction.

\subsection{Description of Methodology}

Due to the small-scale nature of this study, a decision was made to focus on insights from one country (Austria) and include insights from lecturers from all 
countries participating. One week after the $\mathrm{CBBC}$, the researcher from Vienna conducted a group "Zoom" feedback session with the students from Austria and asked for their permission to record for research purposes. Similarly, the following week a de-brief / feedback session was held via "Zoom" with all the lecturers from the universities. The researchers purposefully did not disclose the exact research questions of this paper to avoid any bias in their answers and reflections, as such the analysis was an iterative process in accordance with grounded theory (Trochim \& Donnelly, 2001). The feedback sessions were recorded via smartphone and then transcribed and coded for themes using Atlas Ti. A mix of taxonomic and descriptive codes were used during the first cycle coding (Saldaña, 2013) which included: Ambivalence to Format / Teamwork / Positive or Negative Experience and other in-vivo child codes emerged during analysis. To ensure reliability, the transcripts were reviewed by a research assistant to look for any oversights on codes and themes.

\section{Results}

Themes uncovered were coded and could be clustered around those which were negative or positive towards the online edition of the CBBC. The influence of the pandemic on responses is understood by the context in which the study was conducted. There were a few comments from 2 students who were ambivalent to the format, but notably, these students were those who joined at short-notice due to other students dropping out because of the new online nature. Of interest, the researchers noted that comments from students around it being a "positive learning experience" were stated most frequently, however this does not reflect in the subcodes and themes upon deeper investigation. Of the negative themes to occur on multiple occasions were terms around the feelings of "exhaustion" and "workload" due to the intensity of working on a project intensively, online, for one week, and this could be explained by "Zoom fatigue" (Bozkurt \& Sharma, 2020), since students were experiencing online classes for a few months by the time of the project. After reviewing the written feedback reflection, which was required from students from Austria and the Netherlands from the 2019 face-to-face edition, the only criticism in terms of workload was due to the "intensity" of the week, but there were no references or complaints about it being too much work. Although the 
'Virtually' the same learning outcomes. A case study of a virtual client briefed... $\mid 203$

MONOGRAPH

workload was the same in the online and face-to-face edition, students may have perceived it to be more as the social aspect of meeting each other was missing. Furthermore, it is difficult to create a cut-off point from work in the online world and this increases the inability to "unwind;" a fact which has been confirmed by social science scholars in this field (e.g. Felstead \& Henseke 2017).

A recurring theme to emerge was the idea that the project was "lacking in creativity". Both students and lecturers complained that the project was too strategic and did not allow them to use the full extent of their creative potential. This cannot be put down to the format of this year's $\mathrm{CBBC}$, but rather this was due to the strategic nature of the brief, and perhaps to an extent to the perceived bland product category (adhesive tapes). Some lecturers did however mention that some groups were missing the "big creative idea" but it is inconclusive if this is due to the brief, the group cohesion, the online format or the product category.

A further negative theme was due to communication problems, which appeared to be accentuated in the online edition. The students mentioned that some of the peers from other countries were not as fluent in English as they expected and this created language barriers. However, these language issues were also exacerbated by technology:

The only thing online, I just think, because of the communication is when the Wi-Fi was bad and then people were stuck or froze and then we didn't really understand what the person was saying. But once it was good again, we said you froze. Just say it again, what you said. And so I don't really think that it was because of online only, of course, the freezing thing, but the understanding part. I think it has nothing to do with being online. (Student 5)

However, on a positive note the "International Experience" was a code family identified as it was mentioned several times, as this student recalls:

(..) and then I definitely feel that I learned a lot. The past week, also working with different cultures and with people you just met on the first day. So that was really interesting. And for me personally, I would do it again. Also online, 


\section{MONOGRAPH}

because of the outcome I got from it. Although it was exhausting. I still feel like the outcome was yes more. (Student 1)

Lecturers mentioned several times that they preferred to be part of the faceto-face CBBC. This could be due to the fact that all teaching in this semester was online due to the pandemic and so this was perceived as just another course like those taught at the home universities. The $\mathrm{CBBC}$ offers lecturers a chance to go to another university in another country and spend time connecting and networking with other lecturers. This was lacking in the online edition. As one lecturer mentioned "the personal touch was missing".

The constructivist pedagogy on which the studio classes are based, implies a permanent discussion, a close monitoring of the students' work and a close relationship between them and the instructors. This methodology makes students and teachers almost complicit throughout the development of the projects. In online tutorials, this proximity is very difficult to achieve and social relationships between the members of the teams, and between them and the instructors are less fluid. Several students reported some relationship difficulties - a fact that in previous years and in face-to-face version rarely happened - because "it is easier to deal with incompatibilities and resolve divergences face-to-face than at a distance and through screens" (Student 3). This virtual communicational model also enhances misunderstandings, typical of this virtual channel. Communication and relationship building was hindered due to the fact that each student was in his or her country, with different speeds of internet access and with different levels of mastery of the English language, discussing, trying to reach consensus, and continuing the work. According to some students, this had an impact on the final output of the projects.

Another negative point, felt by one of the teachers and authors of this study, relates to the need for discussion with the students using drawings, sketches, blank sheets, where students and teachers scribble, erase, draw, write and create. This very common reality in open creativity classes becomes very complex and difficult to perform online, as the tools do not yet allow this process to happen with the same simplicity and fluidity as in-person classes. 
'Virtually' the same learning outcomes. A case study of a virtual client briefed... $\mid 205$

A further fact mentioned by the students relates to the difficulty of understanding (and consequently deciding) which way to go, when hearing different feedback from different tutors. In previous face-to-face editions, many of the meetings with the various groups were held together with all, or most of the teachers. Unlike the typical classes at each of the universities, where there is normally only one full professor of the course, so the feedback is unique, and aligned with a single person. In this project, there are several teachers, with different backgrounds and areas of specialties, and even with different opinions on the paths to follow. This was a difficulty mentioned by students at previous editions and in the online version this was exacerbated. The teachers proposed that it was up to the students to listen to the different opinions and, as a group, decide the way forward. After all, the final job is the work of the group, not of the teachers.

Finally, as previously referenced in the literature review, such as the teaching paradox (Sawyer, 2017), several students felt lost because they did not have a solid structure of guidelines to enhance the project, while teachers encouraged them to explore and look for new paths, unexplored communicational territories in order to try to achieve the most original and innovative solutions possible.

\section{Discussion}

This paper reflects on the perceived differences in effectiveness and satisfaction between face-to-face and online (virtual) teaching, with a particular focus on creative projects with the aim to see if the outcomes are "virtually" the same. The findings indicate that the online experience was perceived by students and lecturers on the whole as inferior to the face-to-face edition. However, the formal learning outcomes of the project as described earlier were met, yet the core learning outcome which is very specific to the CBBC "co-operate and collaborate with students from other countries and understand different cultural backgrounds" was only partially met, due to the lack of face-to-face-interaction. The additional learning outcome "work effectively with appropriate tools and strategies online" was certainly achieved. However, this can also be due to the expertise students had learnt due to the Covid-19 pandemic; by May 2020, students were well versed in using online tools. 
Whether students were satisfied with the practical online teaching is inconclusive. The discussions indicated that they certainly enjoyed and benefitted from the practical project however one can draw the conclusion from the reflections that they probably would have been more satisfied had it taken place face-to-face.

The discussion indicates that teaching creativity online differs from classroom teaching in multiple aspects. Although the differences were not obviously visible in the result, they were evident in the process and during the development of the project.

In its characterization of creative teaching, the NACCCE report (1999) made a distinction between teaching for creativity and teaching creatively. In the opinion of the instructors involved in this project, while we did not feel much difference in teaching for creativity, the online experience brought many unexpected challenges for teaching creatively. Teaching for creativity was easier, since the forms of teaching intended to develop students own creative thinking and behavior are much simple to implement. To teach creatively, professors need to use imaginative approaches to make learning more interesting, exciting and effective, and that proved to be harder.

Whether physical or electronic, shared space is essential for successful collaboration as it provides a medium for communication or exchange of ideas (Ahmad et al. 2017). In this instance, the absence of physical presence proved to be an obstacle to the discussion, both among the working groups and with the instructors. As previously mentioned, the possibility of exchanging ideas over drawings, sketches, words, images, etc., is a fundamental pedagogical tool to overcome both students' inhibition and to allow the creative process and, consequently, the ideas to flow. In addition, the creative process lives a lot from enthusiasm, emotion, construction and creation on top of the permanent evolution of the discussion of ideas, so this absence of physical proximity was shown to inhibit this development.

As Amabile (1998) infers, we have to give ourselves permission to create, to generate ideas. Many of them will be inappropriate, foolish, or not useful, but divergent thinking practice helps creativity. It is apparent that the online participation constrains students to come up with, to suggest and to share fresh new ideas 
'Virtually' the same learning outcomes. A case study of a virtual client briefed... | 207

when they are unsure about the potential of those new thoughts. This finding is in line with Fisher (2004), who argued that we are usually more creative when we have others to support us, and the lack of physical presence and face-to-face conversation inhibits this expressiveness.

Communication is another crucial issue in a collaboration project, since continuous communication keeps the collaboration alive and its group members active for the given task. Since this CBBC was carried entirely online, it negatively influenced the flow of the project. This is supported by the writings of Ahmad et al. (2017) that found that teams with continuous communication are more productive than ones where communication occurs frequently but with much more interruptions.

The time and dedication to the projects is also very different when a team is in the same room for the whole week, face-to-face, and exclusively focused on the theme, compared to when each element is in their country, in their home, scheduling online meetings to discuss and advance gradually.

Even though students should have time to evolve, alone (without the presence and accompaniment of tutors), in order to find their own paths, the spatial distance proved to be an obstacle because the instructors were not always available, but rather at previously scheduled days and hours. In other words, since the availability to ask questions, ask for opinions or simply debate a specific point, was not permanent, this fact limited the fluidity of the development of the projects. A core element of studio classes approach, optimal for fostering creativity, is that instructors create a classroom environment where students and instructor act like peers and attempt to avoid a traditional classroom dynamic where the teacher is an authority figure (Salazar, 2013; Vanada, 2016). Our experience indicated that this situation is more difficult to materialize in a virtual environment, where teachers are present only occasionally and, invariably, to listen and approve (or not) the students' creative paths.

The findings of this study should be taken with caution due to the limited number of reflection sessions with insights from just one country and so this study is not generalizable. Richer and more robust insights would have been generated 
from employing focus groups with all participants. A consideration for the future could be to create a hybrid version, where some universities participate virtually and some face-to-face or two independent versions. Certainly, this would facilitate inclusion as per the central goals of internationalisation at home.

\section{References}

Adams, R. S., \& Forin, T. (2016). Characterizing the work of coaching during design reviews. Design Studies, 45, 30-67

Ahmad, W., Stufhaut, M., \& Labianca, J. (2017). Collaborative Dynamics of Creative Teams: Modeling Creative Process in Advertising Design. Business \& Economic Review, 9(4), 157-180. https://doi.org/10.22547/BER/9.4.8

Allen, I. E., \& Seaman, J. (2015). Grade Level: Tracking Online Education in the United States. Babson College, 231 Forest Street, Babson Park, MA 02457: Babson Survey Research Group

Amabile, T. M. (1998), How to kill creativity. Harvard Business Review Sept-0ct: 77-87 Baber, H. (2020). Determinants of students' perceived learning outcome and satisfaction in online learning during the pandemic of COVID-19. Journal of Education and E-Learning Research, 7(3), 285-292.

Bangert, A. (2005). Identifying factors underlying the quality of online teaching effectiveness: An exploratory study. Journal of Computing in Higher Education, 17(2), 79-99

Bozkurt, A., \& Sharma, R. C. (2020). Education in normal, new normal, and next normal: Observations from the past, insights from the present and projections for the future. Asian Journal of Distance Education, 15(2), i-x.

Bransford, J., Brown, A., \& Cocking, R. (Eds.). (2000). How people learn: Brain, mind, experience and school. Washington, DC: National Academy Press

Chen, W. (2016). Exploring the learning problems and resource usage of undergraduate industrial design students in design studio courses. International Journal of Technology and Design Education, 26, 461-487. https://doi.org/10.1007/ s10798-015-9315-2

Clegg, P. (2008) Creativity and critical thinking in the globalized university, Innovations in Education and Teaching International, 45:3, 219-226. https:// doi.org/10.1080/14703290802175982 
'Virtually' the same learning outcomes. A case study of a virtual client briefed... | 209

MONOGRAPH

Crosier, D., Purser, L., \& Smidt, H. (2007). Trends 5: Universities Shaping the European Higher Education Area. EAU

Dow, G. \& Mayer, R. (2004) Teaching students to solve insight problems: Evidence for domain specificity in creativity training, Creativity Research Journal, 16:4, 389-398. https://doi.org/ 10.1080/10400410409534550

Eom, S. B., Wen, H. J., \& Ashill, N. (2006). The determinants of students' perceived learning outcomes and satisfaction in university online education: An empirical investigation. Decision Sciences Journal of Innovative Education, 4(2), 215235. https://doi.org/10.1111/j.1540-4609.2006.00114.X

Felstead, A., \& Henseke, G. (2017). Assessing the growth of remote working and its consequences for effort, well-being and work-life balance. New Technology, Work and Employment, 32(3), 195-212. https://doi.org/10.1111/ntwe.12097

Fisher, R. (2004). What is creativity? In R. Fisher \& M. Williams (Eds.), Unlocking Creativity: Teaching Across the Curriculum. London: David Fulton Publishers Ltd. Gustina, C., \& Sweet, R. (2014). Creatives teaching creativity. International Journal of Art \& Design Education, 33(1), 46-54. https://doi.org/10.1111/j.14768070.2014.01778.X

Jeffrey, B., \& Craft, A. (2004). Teaching creatively and teaching for creativity: Distinctions and relationships. Educational Studies, 30(1), 77-87. https://doi. org/10.1080/0305569032000159750

Jia, C., Hew, K. F., Bai, S., \& Huang, W. (2020). Adaptation of a conventional flipped course to an online flipped format during the Covid-19 pandemic: Student learning performance and engagement. Journal of Research on Technology in Education, 1-21. https://doi.org/10.1080/15391523.2020.1847220

Lindström, L. (2006). Creativity: What is it? Can you assess it? Can it be taught? International Journal of Art \& Design Education, 25(1), 53-66. doi: 10.1111/j.1476-8070.2006.00468.x

Livingston, L. (2010) Teaching Creativity in Higher Education, Arts Education Policy Review, 111:2, 59-62

Karpova, E., Marcketti, S. and Barker, J.(2011), The Efficacy of Teaching Creativity: Assessment of Student Creative Thinking Before and After Exercises. Clothing \& Textiles Research Journal, 29(1) 52-66. https://doi. org/10.1177/0887302X11400065 
Markova, T., Glazkova, I., \& Zaborova, E. (2017). Quality Issues of Online Distance Learning. Procedia - Social and Behavioral Sciences, 237, 685-691. https://doi. org/.1016/j.sbspro.2017.02.043

McWilliam, E. (2009) Teaching for creativity: from sage to guide to meddler. Asia Pacific Journal of Education, 29(3). pp. 281-293. https://doi. org/10.1080/02188790903092787

McWilliam, E., \& Dawson, S. (2008). Teaching for creativity: Towards sustainable and replicable pedagogical practice. Higher education, 56(6), 633-643. https:// doi.org/10.1007/s10734-008-9115-7

NACCCE (National Advisory Committee on Creative and Cultural Education). (1999). All our futures: Creativity, culture and education. London, UK: NACCCE.

Nathan, M. J., \& Sawyer, R. K. (2014). Foundations of the learning sciences. In R. $\mathrm{K}$. Sawyer (Ed.), The Cambridge handbook of the learning sciences (2nd ed., pp. 21-43). New York: Cambridge University Press

Orlov, G., McKee, D., Berry, J., Boyle, A., DiCiccio, T., Ransom, T., ... \& Stoye, J. (2021). Learning during the covid-19 pandemic: it is not who you teach, but how you teach. Economics Letters, 202, 109812. https://doi.org/10.1016/j.econlet.2021.109812

Pezenka, I., Rußmann, U., Schwarzbauer, T., \& Bernhard, J. (2020). 100\% Distance Learning von heute auf morgen - eine Umfrage unter Studierenden an der FHWien der WKW im April 2020. FNMA Magazin - Forum Neue Medien in der Lehre Austria, Sonderausgabe "Plötzlich online“, 38-41. Available online Riffell, S., \& Sibley, D. (2005). Using web-based instruction to improve large undergraduate biology courses: An evaluation of a hybrid course format. Computers \& Education, 44(3), 217-235. https://doi.org/10.1016/j. compedu.2004.01.005

Robinson, K. (2001). Mind the gap: The creative conundrum. Critical Quarterly, 43(1), 41-45.

Runco, M. A. (2004). Creativity. Annual Review of Psychology. 55. 657-687.

Saebø, A. B., McCammon, L. A., \& 0'Farrell, L. (2007). Creative Teaching-Teaching Creativity. Caribbean Quarterly, 53(1-2), 205-215. https://doi.org/10.1080/0 $\underline{0086495.2007 .11672318}$

Salazar, S. M. (2013). Laying a foundation for artmaking in the 21st century: A description and some dilemmas. Studies in Art Education, 54(3), 246-259. https://doi.org/10.1080/00393541.2013.11518897 
'Virtually' the same learning outcomes. A case study of a virtual client briefed... | 211

MONOGRAPH

Saldaña, J. (2013). The coding manual for qualitative researchers. SAGE Publications Limited.

Sawyer, R. K. (2017). Teaching creativity in art and design studio classes: A systematic literature review. Educational Research Review, 22, 99-113. https:// doi.org/10.1016/j.edurev.2017.07.002

Shea, P., Sau Li, C., \& Pickett, A. (2006). A study of teaching presence and student sense of learning community in fully online and web-enhanced college courses. The Internet and Higher Education, 9(3), 175-190. https://doi.org/10.1016/j. iheduc.2006.06.005

Trochim, W. M., \& Donnelly, J. P. (2001). Research methods knowledge base.

Tseng, H. W., \& Walsh Jr, E. J. (2016). Blended vs. traditional course delivery: Comparing students' motivation, learning outcomes, and preferences. Quarterly Review of Distance Education, 17(1)

UNESCO. (2021, May 14). Education: From disruption to recovery. https://en.unesco. org/covid19/educationresponse

Vanada, D. I. (2016). An equitable balance: Designing quality thinking systems in art education. International Journal of Education \& the Arts, 17(11)

Woo, Y., \& Reeves, T. C. (2007). Meaningful interaction in web-based learning: A social constructivist interpretation. The Internet and Higher Education, 10(1), 15-25. https://doi.org/10.1016/j.iheduc.2006.10.005

\section{Notes}

[1] Ted talks (www.ted.com) are influential videos from expert speakers. The talk "School is killing creativity" from Sir Ken Robinson has 65970364 views, by 23th July 2020 (https:// www.ted.com/talks/sir ken robinson do schools kill creativity?language=pt)

\section{(c) $\underset{\mathrm{EY}}{\text { (i) }}$}

Este obra está bajo una licencia de Creative Commons Reconocimiento 4.0 Internacional. 